\title{
Initial Growth and Competitive Ability of Yellow Nutsedge AND IRRIGATED RICE ${ }^{1}$
}

\author{
Crescimento Inicial e Habilidade Competitiva de Tiririca-Amarela e Arroz Irrigado
}

\author{
WESTENDORFF, N.R. ${ }^{2}$, AGOSTINETTO, D. ${ }^{2}$, ULGUIM, A.R. ${ }^{2}$, LANGARO, A.C. ${ }^{2}$, and \\ THÜRMER, L. ${ }^{2}$
}

\begin{abstract}
Weeds cause significant reduction in the irrigated rice crop yield. Cyperus esculentus (yellow nutsedge) is adapted to irrigate environment. Information on the competitive ability of the weed to the culture, and their environmental adaptation, are scarce. In this study, we sought to determine the initial growth and competitive ability of yellow nutsedge and irrigated rice, as a function of cultivar growth cycle. Initial growth and competition studies were conducted in a randomized complete design in a greenhouse in the agricultural year $2010 / 11$. For the initial growth study, the treatments consisted of a factorial combination of a biotype of yellow nutsedge and two rice cultivars in the function of the vegetative cycle (BRS Querência: early cycle - IRGA 424: intermediate cycle) and six evaluation times (10, 20, $30,40,50$, and 60 days after emergence). Were evaluated: plant height, leaf area, aboveground dry biomass and root dry biomass. In the competitive ability study in the replacement series, the cultivar BRS Querência (early cycle) and yellow nutsedge were utilized and tested in different proportions of competition (100:0, 75:25, 50:50, 25:75, and 0:100). Were evaluated leaf area and aboveground dry biomass. In general, rice cultivars have an adaptive value equivalent to yellow nutsedge. IRGA 424 cultivar has less height than weed, becoming the weed control more important in this cultivar. For rice crop, intraspecific competition is more important, whereas for the weed, interspecific competition is the most pronounced.
\end{abstract}

Keywords: Cyperus esculentus, Oryza sativa, competition, fitness.

RESUMO - Plantas daninhas causam grande redução de produtividade das lavouras de arroz irrigado. A espécie Cyperus esculentus (tiririca-amarela) é adaptada ao ambiente irrigado. Informações sobre a habilidade competitiva da daninha com a cultura, e sua adaptação ambiental, são escassas. Os objetivos da pesquisa foram determinar o crescimento inicial e a habilidade competitiva de tiriricaamarela e arroz irrigado, em função do ciclo vegetativo das cultivares. Para isso, foram conduzidos estudos de adaptação e competição, em delineamentos completamente casualizados, em casa de vegetação no ano agrícola 2010/11. Para o estudo de crescimento inicial, os tratamentos constituíramse da combinação fatorial de biótipo de tiririca-amarela e duas cultivares de arroz irrigado em função do ciclo vegetativo (BRS Querência: ciclo precoce; $e$, IRGA 424: ciclo médio) e seis épocas de avaliação (10, 20, 30, 40, 50, e 60 dias após a emergência). Avaliou-se: estatura, área foliar, massa da matéria seca da parte aérea e massa da matéria seca de raizes. Para o estudo de habilidade competitiva foram utilizadas a cultivar de arroz BRS Querência e biótipo de tiririca-amarela, testados em diferentes proporções (100:0, 75:25, 50:50, 25:75 e 0:100). Avaliou-se área foliar e massa da matéria seca da parte aérea. Em geral, as cultivares de arroz estudadas possuem crescimento inicial equivalente a tiririca-amarela. A cultivar IRGA 424 possui estatura inferior à planta daninha tornado o controle prioritário para a cultivar. Para a cultura do arroz, a competição intraespecífica é mais importante, enquanto que para a planta daninha a competição interespecífica é a mais pronunciada.

Palavras-chave: Cyperus esculentus, Oryza sativa, competição, valor adaptativo.

Recebido para publicação em 13.5.2013 e aprovado em 25.6.2013.

Universidade Federal de Pelotas, Capão do Leão-RS, Brasil, <agostinetto@ig.com.br>.

Planta Daninha, Viçosa-MG, v. 31, n. 4, p. 813-821, 2013 


\section{INTRODUCTION}

Rice is the most grown cereal in the world along with corn (FAO, 2010). In Brazil, the southern region is the greatest producer $(72 \%)$ and Rio Grande do Sul state (RS) has the biggest area sown with the crop (40\%), with yields $58 \%$ superior to the national average (CONAB, 2011).

The rice yield average has grown in recent years (IRGA, 2011). Nevertheless, it is still below the expected crop yield potential. Weeds present a negative impact on crop development and yield, causing a yield loss that varies according to the weed species and population, rice cultivar, and management practices adopted (Fleck et al., 2008). Competition occurs when one or more resources needed for development and growth is found under limited amounts to fulfill the demand for all the individuals present in the environment (Radosevich et al., 2007).

Yellow nutsedge (Cyperus esculentus), a Cyperaceae plant, is among the main weeds of rice crop, being able to cause yield losses exceeding $41 \%$ even when taking chemical control measures early (Panozzo et al., 2009). Moreover, yellow nutsedge is highlighted because of their adaptation to wet areas and spread by seed and tubers, which makes control difficult to achieve efficiently. In addition to the direct competition, this species affects crops by exudation soil metabolites with allelopathic properties, which can suppress the development of crops (Buzsáki et al., 2008).

The competition for environmental resources, caused by the weeds to the crops, is included among the main factors that cause yield loss. In fields, the competition occurs when one or more resources that are needed for development and growth are found under limited quantity to attend the necessities of all the individuals present in the environment (Radosevich et al., 2007).

Among the factors that most can alter the competition between species are grown speed and the increasing rate of the competing plants. The fast initial grown and elevated growing rate allows the competitor to precociously occupy the niche. Under theoretical analysis, it is estimated that a $50 \%$ increase in the radial growing rate doubled the competitive ability of a plant (Fischer \& Miles, 1973). Thus, initial growth experiments are capable of informing of the behavior of a species in its ecological niche through time and, therefore, supply knowledge about the competitive ability that is being studied.

To compare the crop's competitiveness with weeds it is possible to use replacement series experiments, which enable the study of competition intra and interspecific. The aim of this experiment type is that the yields of species associations can be determined in comparison to its respective monocultures, and searching indicates which of the biotypes or species is more competitive (Radosevich et al., 2007).

Understanding the competitive ability between species through explanatory variables is an important and helpful tool in weed management to reduce damage. The most adapted individuals are usually more competitive and capable of growing in relative proportion through time, eliminating the less fit to occupy a certain ecological niche (Christoffoleti et al., 1997).

Therefore, the study aimed at investigating and comparing the initial growth and competitive ability of yellow nutsedge with the irrigated rice crop, by initial growth and replacement series experiments.

\section{MATERIAL AND METHODS}

With the aim of evaluating the competitive ability of yellow nutsedge and two irrigated rice cultivars, two studies were conducted in a greenhouse. The first study was to determine the initial growth between yellow nutsedge biotype and rice cultivars BRS Querência and IRGA 424, and the second one was to study the competitive ability of the yellow nutsedge biotype and the irrigated rice cultivar BRS Querência, in a replacement series experiment. All experiments were conducted in a randomized complete block design with four replications.

The first study was conducted from December 2010 to February 2011, being the experimental units, pots with an $8 \mathrm{~L}$ capacity and $23 \mathrm{~cm}$ diameter, filled with soil. The soil 
fertility correction was according to the soil analysis, following recommendations for an irrigated rice crop (SOSBAI, 2010).

The treatments included yellow nutsedge biotype and two irrigated rice cultivars: BRS Querência (early cycle) and IRGA 424 (medium cycle); and five sampling times (20, 30, 40, 50, and 60 days after emergence (DAE)). Five seeds per pot from each cultivar were sown, with a thinning on the seven DAE leaving only one plant of rice per experimental unit. Soil infested with yellow nutsedge was put into plastic trays where the emergence of seedlings and on the seven DAE would then occur, and the plants with a similar number of leaves as the rice cultivars were transplanted to the experimental units. The variables evaluated each time were: plant height $(\mathrm{H})$, leaf area (LA), aboveground dry biomass (AB) and dry root biomass (RB). The $\mathrm{H}$ was measured with the millimeter ruler, covering the distance between the soil and apex of the plant. After the plants cut, at level soil, the leaves were separated in order to evaluate the LA, with the leaf area meter (model LI 3100C) and the leaves being placed in a paper bag and dried in an oven with forced air circulation at a temperature of $60{ }^{\circ} \mathrm{C}$ until constant mass when they were then weighted for $A B$ quantification. To quantify $\mathrm{RB}$, the roots were washed under tap water to eliminate the added soil. The drying and weighting roots occurred in a similar way as in $\mathrm{AB}$.

The data obtained was then analyzed as to its normality and homoscedasticity, and then submitted to ANOVA ( $\mathrm{p} \leq 0.05)$. The found statistical significance and means for the species factor were analyzed by the Duncan test $(p \leq 0.05)$ and applied analyses of regression $(p \leq 0.05)$ for the sampling time factor.

To verify the competitive ability between yellow nutsedge and irrigated rice (study 2), two experiments were conducted. The first experiment, with monocultures of yellow nutsedge and cultivar rice BRS Querência aimed at determining the plants population from $A B$, in grams $(\mathrm{g})$ per area unit $\left(\mathrm{m}^{-2}\right)$, becomes independent from the population, according the constant final yield law (Radosevich et al., 2007). The populations studied were $28,58,115,231,462,923$, and 1,847 plants $\mathrm{m}^{-2}$. The experimental units and ownership of the seedlings of yellow nutsedge were identical to what was written in study 1 . The plants' leaves were collected at 42 DAE to determine the $A B$, which was analyzed using reciprocal production. The population where $A B$ became independent from its population of plants, considering the average between the rice cultivar and the infesting weed, was of 978 plants $\mathrm{m}^{-2}$ (data not showed).

The second experiment was conducted on replacement series with 32 plants per experimental unit, corresponding to a population of 978 plants $\mathrm{m}^{-2}$, which was determined in the previous experiment. The treatments included the proportions of yellow nutsedge and irrigated rice cultivar BRS Querência. The proportions tested were: 100:0 (BRS Querência cultivar pure stand), 75:25, 50:50, 25:75, and 0:100\% (yellow nutsedge biotype pure stand). The cultivar sowing and transplant of weeds were in populations that are superior to the ones desired in each treatment with a thinning on the seven DAE. The soil of the experimental units was irrigated as much as needed until the definite irrigation done on the seven DAE.

The evaluated variables at $42 \mathrm{DAE}$ were LA and $A B$, being quantified identically as described before. To analyze the data of the competitors variables $\mathrm{LA}$ and $\mathrm{AB}$, the method of graphical analyses of relative yield was used (Bianchi et al., 2006). The relative competitive index $(\mathrm{RC})$ and relative groupings' coefficients (K) and competitiveness (C), as written by Cousens (1991), Cousens \& O'Neill (1993), and Bianchi et al. (2006) were all calculated.

The specie $\mathrm{X}$ is more competitive than $\mathrm{Y}$ when $\mathrm{RC}>1, \mathrm{Kx}>\mathrm{Ky}$ e $\mathrm{C}>0$; on the other hand, the specie $\mathrm{Y}$ is more competitive than $\mathrm{X}$ when $\mathrm{RC}<1, \mathrm{Kx}<\mathrm{Ky} \mathrm{e} \mathrm{C}<0$ (Hoffman \& Buhler, 2002). The procedure of statistical analyses of yield or relative variation includes the calculation of the differences for the values of relative yield (RY) and the criteria to consider the curves of RY and relative yield total (RYT) different from the hypothetical lines followed the directions from Bianchi et al. (2006). For the indexes RC, K, and C, it was considered the existence of competitive differences when, in at least two of them, there is a significant difference in the " $t$ " test $(\mathrm{p} \leq 0.05)$.

Planta Daninha, Viçosa-MG, v. 31, n. 4, p. 813-821, 2013 
The results obtained for $A B$ and $L A$, expressed in mean value by treatment, were submitted to a variance analyses by the $F$ test $(p \leq 0.05)$; and being significant, the Dunnett test $(p \leq 0.05)$ treatments means were compared, considering their respective monocultures as comparison witnesses.

\section{RESULTS AND DISCUSSION}

For data from initial growth of yellow nutsedge and irrigated rice crop, the normality test did not show the necessary data transformation. There was an interaction of the treatment factors for the variables $\mathrm{H}$, LA, and $\mathrm{AB}$ (Figures 1, 2, and 3). For the variable $\mathrm{RB}$, there was only an effect over the factor seasons samplings (Figure 4).

$\mathrm{H}$ adjusted itself satisfactorily to the exponential regression model, presenting a coefficient of determination $\left(\mathrm{R}^{2}\right)$ of 0.98 , as much for the yellow nutsedge biotype as for both rice cultivars. For this variable, an increase throughout the sampling times was observed, for both yellow nutsedge and the rice cultivars. This result was expected in that, with the development of species over time, the value of this variable increases, due to the growth plant. Considering the value of the equation exponent, it was found that BRS Querência presented a larger increase in height through the period of evaluation (Figure 1).

$\mathrm{H}$, the rice cultivars and yellow nutsedge biotype had the same behavior until the 30 DAE, without differences between species on the 30 DAE. However, from 30 DAE onward, there was a difference between the rice cultivars. Overall, in all samplings, the weed did not differ from BRS Querência cultivar, except at 50 DAE, and overcame the IRGA 424 cultivar at 40 DAE. This result suggests than yellow nutsedge has a competitive advantage in relation to the IRGA 424 cultivar, but does not differ from the BRS Querência cultivar. Such a behavior may result from IRGA 424 having a smaller stature, which disfavors the interception of solar radiation, as the main feature of competition between rice and weeds (Fleck et al., 2003). It is noteworthy that the difference of height observed among irrigated rice cultivars cannot be considered because the lower height is a characteristics of IRGA 424 cultivar in comparison to BRS Querência (SOSBAI, 2010) (Figure 1).

So there is shading of weeds by crops, it is necessary, in addition to ground cover,

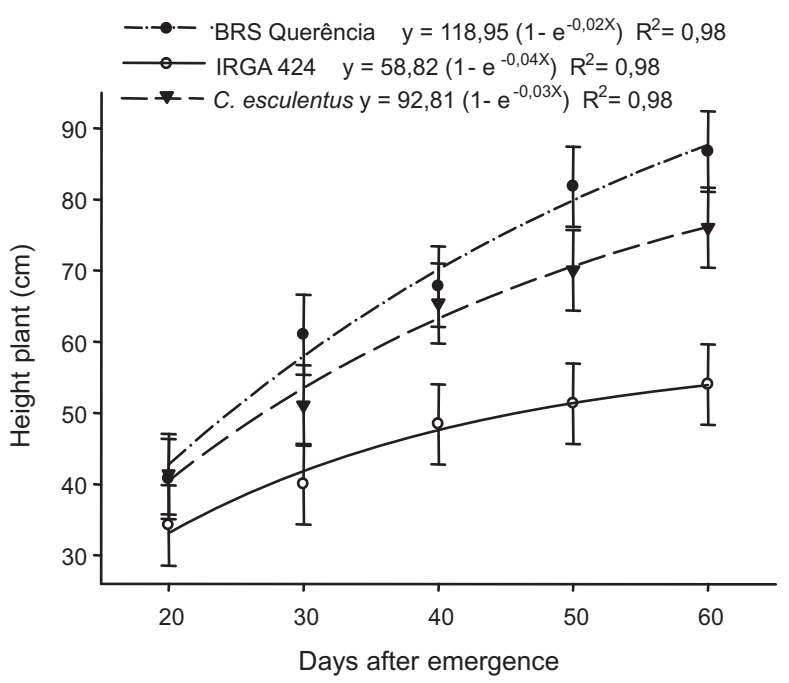

The points represent the mean values of replicates of each species and the bars the confidence intervals for each species.

Figure 1 - Height of yellow nutsedge (Cyperus esculentus) biotype and rice cultivars (IRGA 424 and BRS Querência), evaluated at 20 to 60 days after emergence.

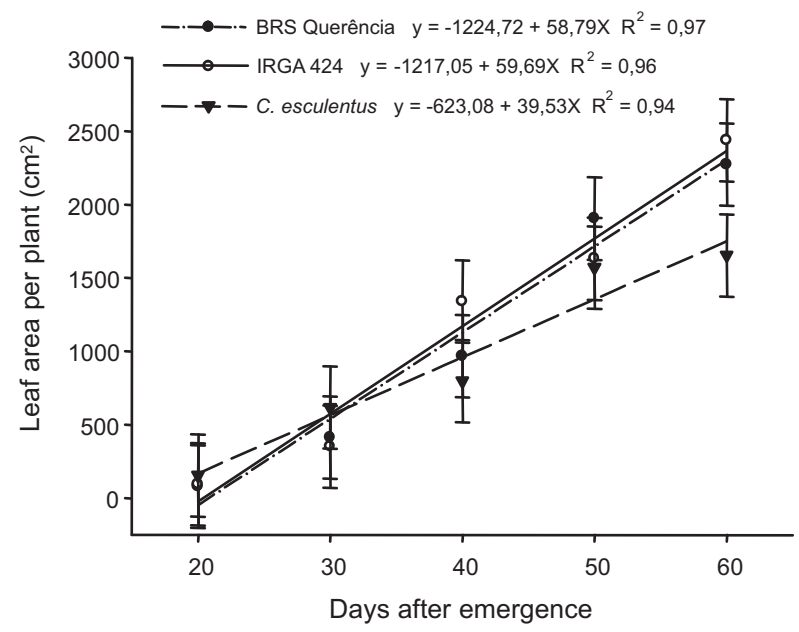

The points represent the mean values of replicates of each species and the bars the confidence intervals for each species.

Figure 2 - Leaf area of yellow nutsedge (Cyperus esculentus) biotype and rice cultivars (IRGA 424 and BRS Querência), evaluated at 20 to 60 days after emergence. 


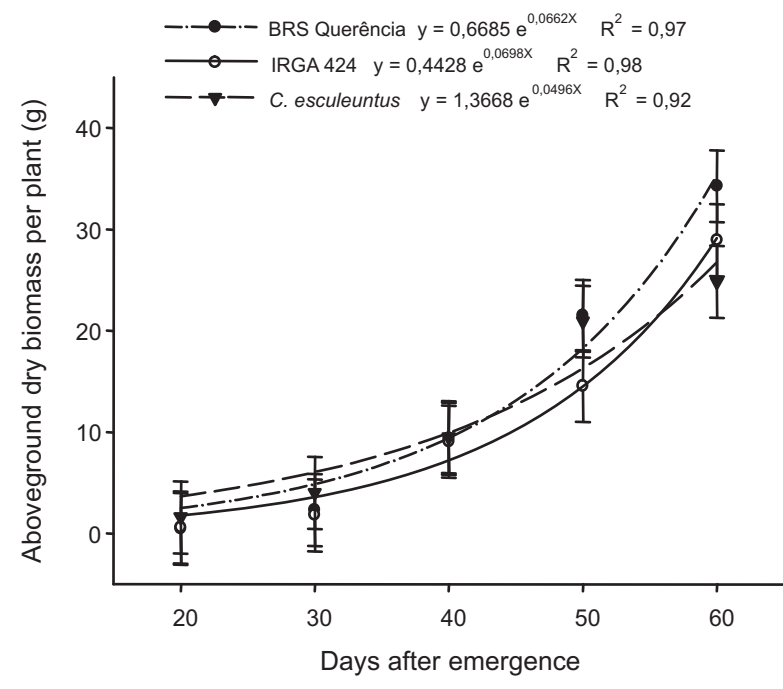

The points represent the mean values of replicates of each species and the bars the confidence intervals for each species.

Figure 3 - Aboveground dry biomass of yellow nutsedge (Cyperus esculentus) biotype and rice cultivars (IRGA 424 and BRS Querência), evaluated at 20 to 60 days after emergence.

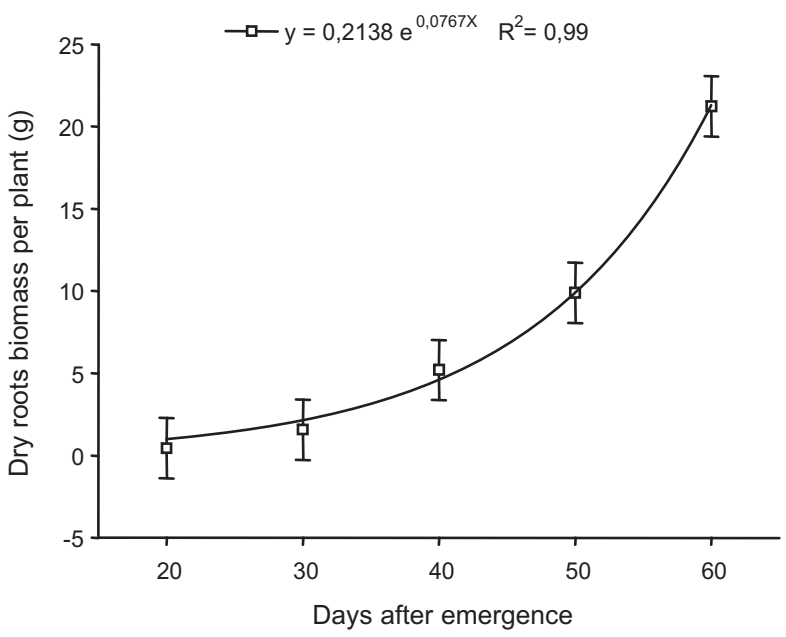

The points represent the mean values of replicates of each species and the bars the confidence intervals for each species.

Figure 4 - Dry root biomass of yellow nutsedge (Cyperus esculentus) biotype and rice cultivars (IRGA 424 and BRS Querência), evaluated at 20 to 60 days after emergence.

plant height higher, which enables greater energy capture light in the upper canopy (Fleck et al., 2003). Thus, plants whose characteristics require less skill in capturing light (such as smaller stature) have a competitive disadvantage by light.
In competition with red rice (Oryza sativa) and the rice cultivar EEA 406 (simulator of competitor red rice), the cultivar IRGA 417 had its stature affected negatively by competition (Fleck et al., 2008). The stature is an important morphological characteristic of plants with regard to competition among species (Radosevich et al., 2007; Fleck et al., 2008). For cultivar IRGA 424, the inferior plant height in comparison to the weeds, imposes less competitive potential (Figure 1), especially on light capture. Therefore, for seizing the yield potential of this cultivar, the weed control should be performed early. For LA variable, there was linear growth, as of yellow nutsedge biotype, as of rice cultivars, where the determination coefficients varied between 0.94 and 0.97 (Figure 2).

There was not a difference between the cultivars in sampling times and both outgrew the weeds only on 60 DAE. Comparing the line inclinations, it was noticed that the rice cultivars presented a larger production of LA, comparably to weeds (50\% superior average). The exponential model also showed a satisfactory adjustment of variable $A B$ data, with determination coefficients between 0.92 and 0.98. At $40 \mathrm{DAE}$, the species experimented greater accumulation of $\mathrm{AB}$, but only at $60 \mathrm{DAE}$ was there a difference between BRS Querência cultivar and yellow nutsedge, with an advantage for the first one (Figure 3 ).

The accumulation and mass allocation are important characteristics for the understanding of competitive ability among plants (Radosevich et al., 2007). The weed Digitaria insularis has a slow accumulation of dry matter of shoots until 45 DAE, showing that crops in competition with slow growth consequently lack a niche domain and can have an inferior competitive ability compared to weeds (Machado et al., 2006).

For variable RB, there was no interaction between species and sampling times, there was an adjustment of exponential model and the determination coefficient $\left(\mathrm{R}^{2}\right)$ was of 0.99 (Figure 4). Generally, slow growth was observed until $40 \mathrm{DAE}$, being more pronounced after this time of the evaluation. On similar notes, the Digitaria insularis radical system growth was slow until $45 \mathrm{DAE}$, meanwhile on a posterior period (105 DAE), it started 
accelerating due to rhizomes formation, providing the weeds under this growing period a great capacity of soil's resources appropriation (Machado et al., 2006).

For competitive ability, the study between yellow nutsedge and irrigated rice, under replacement series (study 2), the normality test showed it to not be necessary to process data. The graphical analyses of results that were obtained for RY, referring to variables $A B$ and LA, showed that rice was more competitive than the yellow nutsedge biotype, because the $\mathrm{RY}$ of rice was represented by the concave line and yellow nutsedge by convex line (Figure 5).

The competition between two species occurred by the same resources of the surroundings, those being used more efficiently by rice. Considering that there exists a difference between the hypothetical lines should have significance, at least, on two plants proportions (Bianchi et al., 2006), and it was noticed that the deviations of RY of crop and weed, for variable $A B$, were significant on proportions 50:50 and 25:75 (Table 1), thereby corroborating the visual graphics interpretation and showing that there was a benefit for the crop and damage to the weed.

For LA variable, there was only a decrease of weed RY on proportions 50:50 and 25:75 (Table 1 ). In relation to RYT, there was no difference between what was expected and what was observed for none of the studied variables. However, numerical and graphically,

Table 1 - Relative differences for the variables aboveground dry biomass and leaf area of rice cultivar BRS Querência and yellow nutsedge (Cyperus esculentus) biotype

\begin{tabular}{|l|c|c|c|}
\hline \multirow{2}{*}{ Variable } & \multicolumn{3}{|c|}{ Proportion of associated plants (rice : yellow } \\
& $75: 25$ & $50: 50$ & $25: 75$ \\
\cline { 2 - 5 } & \multicolumn{4}{|c|}{ Aboveground dry biomass } \\
\hline & $0.15( \pm 0.07)$ & $0.21( \pm 0.02)^{*}$ & $0.02( \pm 0.01)^{*}$ \\
\hline Rice & $-0.04( \pm 0.04)$ & $-0.23( \pm 0.02)^{*}$ & $-0.25( \pm 0.06)^{*}$ \\
\hline Yellow nutsedge & $0.98( \pm 0.04)$ & $0.98( \pm 0.01)$ & $0.90( \pm 0.01)^{*}$ \\
\hline Total & \multicolumn{4}{|c|}{ Leaf area } \\
\hline & $-0.003( \pm 0.03)$ & $0.16( \pm 0.05)^{*}$ & $0.13( \pm 0.05)$ \\
\hline Rice & $-0.03( \pm 0.03)$ & $-0.20( \pm 0.02)^{*}$ & $-0.25( \pm 0.04)^{*}$ \\
\hline Yellow nutsedge & $0.97( \pm 0.03)$ & $0.96( \pm 0.04)$ & $0.88( \pm 0.03)^{*}$ \\
\hline Total & $0.9-\cdots$
\end{tabular}

* Significant difference by "t" test $(\mathrm{p} \leq 0.05)$. Values in parentheses represent standard errors of means.
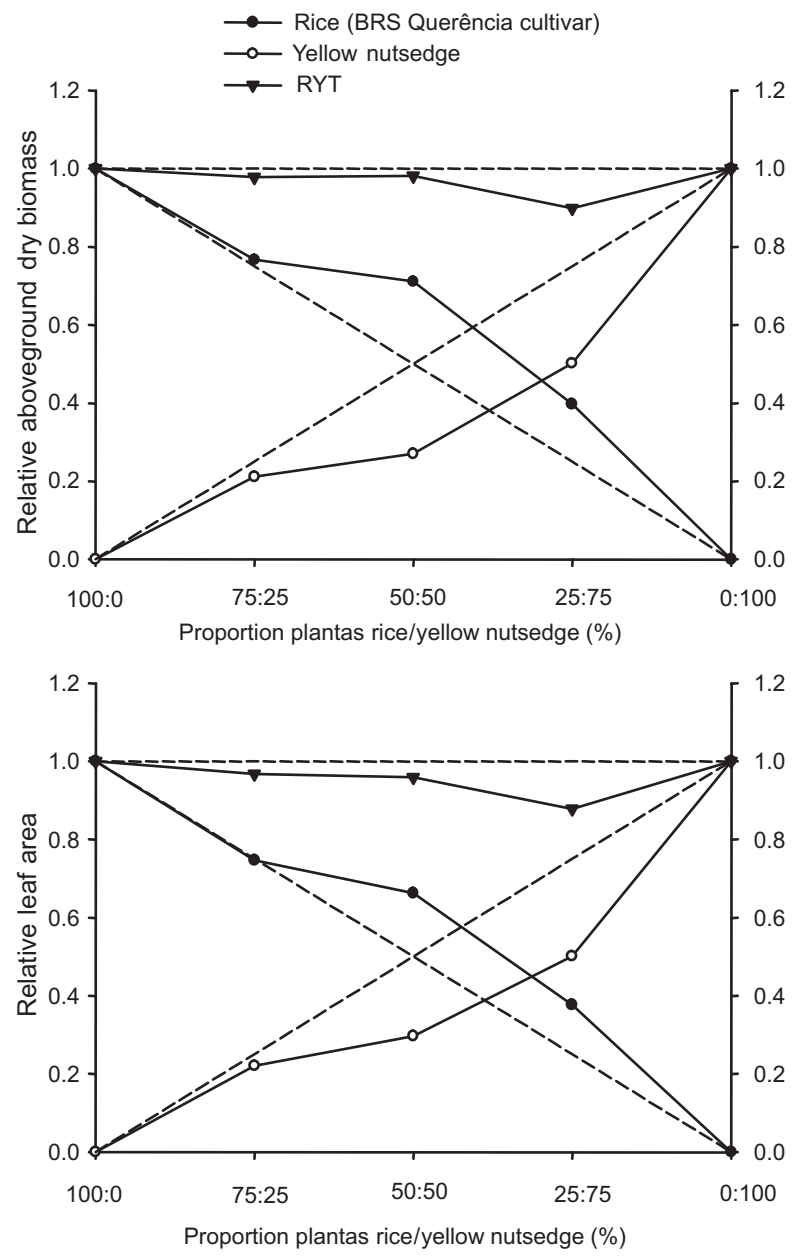

Filled circles $(\bullet)$ and empty (O) represent the RY of LA and SB of Rice and Yellow nutsedge, respectively, and $(\boldsymbol{\nabla})$ indicates a RYT. The dashed lines refer to the hypothetical relative yield, when there is no interference of one species over another.

Figure 5 - Relative yield (RY) and total (RYT) Leaf area (LA) and aboveground dry biomass (SB) yellow nutsedge (Cyperus esculentus) biotype and rice cultivar (BRS Querência), dependent on the proportion of plants.

it was noticed that on the minor rice proportion, for both variables, antagonism in association occurred (Figure 5, Table 1).

The results showed that the intra-specific competition to rice was more important than an inter-specific one, which is a fact that is proven by the increasing of RY of crop on two largest proportions of weed (50:50 and 25:75) (Figure 5, Table 1). On the other hand, to weeds, the inter-specific competition was more pronounced and, once it occurred, a decrease of RY on same proportions occurred. On a 
similar note, competition studies Cyperus difformis biotypes (Dal Magro et al., 2011), and with Fimbristylis miliacea (Schaedler, 2011), indicated through the variables $\mathrm{AB}$ and $\mathrm{LA}$ that rice is more competitive than competitors.

In an opposite way than what was shown for the association of rice and yellow nutsedge, the competition of red rice crop showed through an LA variable, and a decrease of RY on the higher and lowest plants proportion (Fleck et al., 2008). As for AB, the authors noticed a decrease of RY for crops as regards all proportions of plants and an increase of RYT, resulting in red rice's RY increase.

Assuming rice is more competitive than yellow nutsedge when $\mathrm{RC}>1, \mathrm{Kx}>\mathrm{Ky}$ and $\mathrm{C}>0$ (Hoffman \& Buhler, 2002) and using this criteria to prove its competitive superiority, and evidence of differences in at least two of these indexes (Bianchi et al., 2006), it was observed, for all evaluated variables, that the crop has more competitiveness than weeds (Table 2), and the results were corroborated by graphical analyses. Similar indexes were observed when the rice competed with Cyperus difformis biotypes (Dal Magro et al., 2011) and Fimbristylis miliacea (Schaedler, 2011). On the other hand, rice was less competitive than red rice (Fleck et al., 2008) and barnyardgrass (Agostinetto et al., 2008), and followed the referred assumptions of competition hierarchy.

The study showed that, generally, the crop is more competitive than the weed species because the weed effect is not only due to greater individual competitive ability, but mostly field condition and the total population of weeds (Vilá et al., 2004). To red rice, morphophysiological similarities with cultivated rice and, mostly, its higher plant height, maximizes its competition for light, reflecting other explanatory variables, which makes weeds more competitive than rice (Agostinetto et al., 2001; Fleck et al., 2008). For yellow nutsedge opposite results were noticed once its lower stature, when compared to rice cultivar BRS Querência (Figure 1, study 1), can minimize light competition.

To AB and LA variables, a larger means for rice plants was found when the crop had a lower proportion of plants, confirming the inference that, for rice, intra-specific competition was more expressive than inter-specific (Table 3).

Table 2 - Competitiveness indices between rice cultivar BRS Querência and yellow nutsedge (Cyperus esculentus) biotype, expressed as relative competitive index (RC), groupings coefficients on (K) and competitiveness (C)

\begin{tabular}{|c|c|c|c|c|}
\hline \multirow{2}{*}{ Variable } & RC & Kx (rice) & Ky (yellow nutsedge) & C \\
\cline { 2 - 5 } & \multicolumn{4}{|c|}{ Rice X yellow nutsedge } \\
\hline AB & $2.70( \pm 0.30)^{*}$ & $2.53( \pm 0.29)^{*}$ & $0.37( \pm 0.04)$ & $0.44( \pm 0.04)^{*}$ \\
\hline LA & $2.29( \pm 0.28)^{*}$ & $2.20( \pm 0.58)^{*}$ & $0.43( \pm 0.05)$ & $0.37( \pm 0.06)^{*}$ \\
\hline
\end{tabular}

* Significant difference by " $\mathrm{t}$ ” test $(\mathrm{p} \leq 0.05)$. Values in parentheses represent standard errors of means. $\mathrm{K}_{\mathrm{x}}$ e $\mathrm{K}_{\mathrm{y}}$ are coefficients groupings on the rice cultivar and competitive, respectively. SB: Dry shoots biomass of. LA: Leaf area.

Table 3 - Differences between plants associated or not the rice cultivar BRS Querência with yellow nutsedge (Cyperus esculentus) for aboveground dry biomass and leaf area

\begin{tabular}{|c|c|c|c|c|}
\hline \multirow{2}{*}{$\begin{array}{c}\text { Associated plants } \\
\text { Rice/yellow nutsedge }\end{array}$} & \multicolumn{2}{|c|}{$\begin{array}{c}\text { Aboveground dry biomass } \\
(\mathrm{g} \text { per plant) }\end{array}$} & \multicolumn{2}{c|}{ Leaf area (cm per plant) } \\
\cline { 2 - 5 } & Rice & Yellow nutsedge & Rice & Yellow nutsedge \\
\hline $100: 0(\mathrm{C})$ & 0.77 & - & 86.53 & - \\
\hline $75: 25$ & 0.79 & $0.78^{*}$ & 86.15 & 80.35 \\
\hline $50: 50$ & 1.10 & $0.63 *$ & 114.67 & $53.99 *$ \\
\hline $25: 75$ & $1.22 *$ & 0.98 & $130.39 *$ & $60.82 *$ \\
\hline $0: 100(\mathrm{C})$ & - & 1.16 & - & 91.02 \\
\hline $\mathrm{CV}(\%)$ & 21.96 & 22.53 & 20.65 & 21.23 \\
\hline
\end{tabular}

* Means differ from control by Dunnet test $(p \leq 0,05)$. CV: coefficient of variation. 
For yellow nutsedge, the largest means by plant occurred when the weed was in equivalence with the plants $(50: 50)$ or in a lower proportion (75:25), for both variables, indicating the most important competition for this species is interspecific, especially by the decrease of variables when compared to the respective monoculture (Table 3).

Similar results were observed under a study of rice competition (cultivar BRS Querência) with Cyperus difformis biotypes (Dal Magro et al., 2011). For this weed, LA and $A B$ variables decreased in all the proportions of competing plants, indicating intra-specific competition, for the crop was more pronounced. The rice cultivar EPAGRI 109 showed, for variables LA and AB, a higher yield by plant in lower proportions in competition with Fimbristylis miliacea biotypes, resistant, and susceptible to ALS inhibitors, also indicating a greater importance of intra-specific competition for crops (Schaedler, 2011).

On the other hand, for rice cultivar IRGA 417, in competition with red rice, the opposite results to LA were observed, on higher and lower proportion of the plants crop in relation to the weeds, and a decrease on all proportions for variable $\mathrm{AB}$, indicating that, for this particular cultivar, the interspecific competition is more important (Fleck et al., 2008). Likewise, the cultivars IRGA 417 and BR-IRGA 410 were affected by the competition with barnyardgrass on all proportions of competing plants, for the referred variables, indicating the competitive superiority of barnyardgrass to these rice cultivars (Agostinetto et al., 2008). It is worth pointing out that both competitors, red rice and barnyardgrass, belong to the same botanical family and have morphophysiological characteristics that are more similar to rice crop, as Cyperus difformis, Fimbristylis miliacea, and Cyperus esculentus, belong to the Cyperaceae family, distinguishing itself, morphophysiologicaly, from the crop. Generally, losses in crop yields, due to weed competition, increase the more similar are the morphological and physiological characteristics among competitors by exploiting more intensely the same ecological niche (Lamego et al., 2004).
Therefore, studies showed overall that the irrigated rice cultivars BRS Querência and IRGA 424 have equivalent initial growth to the yellow nutsedge biotype. The rice cultivar BRS Querência showed superior competitive ability versus the yellow nutsedge biotype, whereas for the rice crop, the intra-specific competition prevails, as for yellow nutsedge the interspecific competition is more important.

\section{LITERATURE CITED}

AGOSTINETTO, D. et al. Competitividade relativa entre cultivares de arroz irrigado e biótipo de capim-arroz

(Echinochloa spp.). Planta Daninha, v. 26, n. 4, p. 757-766, 2008.

AGOSTINETTO, D. et al. Arroz vermelho: ecofisiologia e estratégias de controle. Ci. Rural, v. 31, n. 2, p. 341-349, 2001.

BIANCHI, M. A. et al. Proporção entre plantas de soja e plantas competidoras e as relações de interferência mútua. Ci. Rural, v. 36, n. 5, p. 1380-1387, 2006.

BUZSÁKI, K. et al. The allelopathic effect of yellow nutsedge (Cyperus esculentus) on cultivated plants and common ragweed (Ambrosia artemisiifolia L.). J. Plant Dis. Protect., v. 21, p. 327-331, 2008, Supplement.

CHRISTOFFOLETI, P. J. et al. Growth analysis of sulfonylurea resistant and susceptible kochia (Kochia scoparia). Weed Sci., v. 45, n. 5, p. 691-695, 1997.

CONAB. Arroz - Brasil. Série histórica de área, produtividade e produção. Disponível em: <http://www.conab.gov.br>. Acesso em: 22 set. 2011.

COUSENS, R. D. Aspects of the design and interpretation of competition (interference) experiments. Weed Technol., v. 5, n. 3, p. 664-667, 1991.

COUSENS, R. D.; O’NEILL, M. Density dependence of replacement series experiments. Oikos, v. 66, n. 2, p. 34-352, 1993.

DAL MAGRO, T. et al. Habilidade competitiva entre biótipos de Cyperus difformis L. resistente ou suscetível a herbicidas inibidores de ALS e destes com arroz irrigado.

Bragantia, v. 70, n. 2, p. 294-301, 2011.

FOOD AND AGRICULTURE ORGANIZATION OF THE UNITED NATIONS - FAO. Production of cereals and share in world (2010). Disponível em: <http:// faostat.fao.org/site/339/default.aspx>. Acesso em: 17 jul. 2012. 
FISCHER, R. A.; MILES, R. E. The role of spatial pattern in the competition between crop plants and weeds: A theoretical analysis. Math. Biosci., v. 18, n. 3-4, p. 335-350, 1973.

FLECK, N. G. et al. Competitividade relativa entre cultivares de arroz irrigado e biótipo de arroz-vermelho.

Planta Daninha, v. 26, n. 1, p. 101-111, 2008.

FLECK, N. G. et al. Velocidade de estabelecimento em cultivares de arroz irrigado como característica para aumentar a habilidade competitiva com plantas concorrentes.

Ci. Rural, v. 33, n. 4, p. 635-640, 2003.

HOFFMAN, M. L.; BUHLER, D. D. Utilizing Sorghum as a functional model of crop-weed competition. I. Establishing a competitive hierarchy. Weed Sci., v. 50, n. 4, p. 466-472, 2002.

INSTITUTO RIO-GRANDENSE DO ARROZ - IRGA. Séries históricas. Disponível em: <http://www.irga.rs.gov.br/ uploads/1318871736PRODARRS__serie_historica.pdf>. Acesso em: 25 set. 2011.

LAMEGO, F. P. et al. Tolerância à interferência de plantas competidoras e habilidade de supressão por genótipos de soja - II. Resposta de variáveis de produtividade.

Planta Daninha, v. 22, n. 4, p. 491-498, 2004.
PANOZZO, L. E. et al. Métodos de manejo de Cyperus esculentus na lavoura de arroz irrigado. Planta Daninha, v. 27, n. 1, p. 165-174, 2009.

MACHADO, A. F. L. et al. Análise de crescimento de Digitaria insularis. Planta Daninha, v. 24, n. 4, p. 641-647, 2006.

RADOSEVICH, S. R. et al. Ecology of weeds and invasive plants: relationship to agriculture and natural resource management. 3.ed. New York: John Wiley \& Sons, 2007. 454 p.

SCHAEDLER, C. E. Resistência de Fimbristylis miliacea (L.) Vahl aos herbicidas inibidores da enzima ALS. 2011. 126 f. Tese (Doutorado em Fitossanidade) - Faculdade de Agronomia “Eliseu Maciel”, Universidade Federal de Pelotas, Pelotas, 2011.

SOSBAI. Arroz irrigado: recomendações técnicas da pesquisa para o sul do Brasil. Porto Alegre: Pallotti, 2010. $188 \mathrm{p}$.

VILÁ, M. et al. Competition experiments on alien weeds with crops: lessons for measuring plant invasion impact? Biol. Invas., v. 6, n. 1, p. 59-69, 2004. 